\title{
Can prosthetic limbs made too quickly cause kidney damage?: a pilot study
}

\author{
Jerrold S. Petrofsky ${ }^{a}$, Mary Browne, Mahyar Jamshidi, Anthony Libo-on, Haneul Lee ${ }^{a}$ \\ ${ }^{a}$ Department of Physical Therapy, School of Allied Health Professions, Loma Linda University, Loma Linda, CA, USA \\ ${ }^{\mathrm{b}}$ Program in Orthotics and Prosthetics, Department of Physical Therapy, School of Allied Health Professions, Loma Linda University, Loma \\ Linda, CA, USA
}

Objective: The use of chemicals for building prosthetic sockets present the possibility of being hazardous and unsafe due to off-gassing. The purpose of the present study was to investigate if freshly made materials used in prosthetic sockets causes off-gassing that would penetrate the skin and cause damage to the kidneys or blood.

Design: Cross-sectional study.

Methods: In this research, the off-gassing effects during the initial curing process of styrene monomer, vinyl ester resin, epoxy methacrylate resin, benzene-1, 3-dimethaneamine, trimethylhexanedlamine, and paratertiarybutylphenol were analyzed. Acid detection strips were placed inside newly fabricated mock-prosthetic sockets and left overnight in a closed environment to find out if acid was present in the invisible fumes. The plastic was worn by 9 subjects and urinalysis was made after 48 hours to test for any kidney or blood toxicity of the resins.

Results: After wearing the plastic cuff for 48 hours, the ratio of protein to creatinine in the urine was raised to an abnormal level in five out of nine subjects. Four out of the nine subjects showed normal protein to creatinine ratios after wearing the device. The results showed that damage to the kidney occurred from wearing the resins after curing in half of the subjects.

Conclusions: It is very important to conduct patient intakes which includes the assessment of renal function. Off-gassing in vented chambers may be needed to protect both prosthetists and patients.

Key Words: Chemicals in acrylic resin, Off-gassing, Prosthetics

\section{Introduction}

There are approximately 1.7 million people living with limb loss in the United States [1]. It is estimated that one out of every 200 people in this country has had an amputation [2]. The majority of these amputations are as a result of vascular insufficiency, especially from the complications of diabetes [3]. Currently, there are roughly 185,000 amputations per year performed in the United States [1]. The number of amputations due to trauma and cancer are declining annually, yet the amputations that occur due to vascular complications are increasing [1].

Survival rates after amputation vary based on a number of factors. Traumatic amputations tend to have positive long-term prognosis [4,5]. Peripheral arterial disease and diabetes face a $9 \%-15 \%$ thirty day mortality rate after amputation with long term survival rate of $60 \%$ at one year [6]. After three years, the survival rate is $42 \%$ and then $35 \%-45 \%$ five years after amputation. There is a significant demand for prosthetics which enable the amputee to regain former function to maintain personal independence as well as provide cosmesis [7].

The development of prosthetics began thousands of years ago. The oldest surviving prosthetic device was a wooden toe found on a female mummy in Egypt (about 1000 BCE). The history of prosthetic materials has advanced from wood

Received: 3 November, 2014 Revised: 28 November, 2014 Accepted: 30 November, 2014

Corresponding author: Haneul Lee

Department of Physical Therapy, School of Allied Health Professions, Loma Linda University, 11234 Anderson St., Loma Linda, CA 92350, USA Tel: 1-909-558-7274 Fax: 1-909-558-0481 E-mail: hlee@llu.edu

(c) This is an Open-Access article distributed under the terms of the Creative Commons Attribution Non-Commercial License (http://creativecommons.org/licens es/by-nc/3.0) which permits unrestricted non-commercial use, distribution, and reproduction in any medium, provided the original work is properly cited.

Copyright $@ 2014$ Korean Academy of Physical Therapy Rehabilitation Science 
(the "peg" leg) to modern computerized bionic devices which employ synthetic joints and socket materials.

Hippocrates (460-377 BCE) introduced surgical amputation as the only way to save lives of patients threatened by the impact of necrotic tissue, regardless of causation, and that of localized infection spreading to their critical organs. Any bleeding was controlled by cauterization. Later on, Pare (1509 to 1590 BCE) made an improvement to surgical methods by utilizing ligatures rather than cauterization to stop bleeding. As mortality rates improved with amputation procedures, the need for prosthetics increased and evolved [7].

In 1863, Parmelee of New York City made an improvement to the attachment of artificial limbs by attaching a prosthetic socket to the limb with atmospheric compression. The design of the upper limb socket was influenced by different variables pertaining to material science and biomechanical engineering, with the intention of maximizing range of motion, providing stability, and distributing forces upon it for greater comfort. As socket designs have evolved, so have prosthetic materials. Early prosthetists manufactured wooden sockets which they believed would contour the residual limb the greatest. Discussion regarding the benefits of specific force distribution of lower limb applications started in early 1900, at the time the duplication of residual limb was done through measurements and plaster impressions. Wood and leather was later replaced by aluminum and laminates plastic [7-9]. By using transparent petrochemicals in building sockets, more flexibility and comfort is afforded. But these chemicals have the possibility of being hazardous and unsafe due to the off-gassing, facilitating movement of carcinogens and endocrine disrupting chemicals to the patient [10-16]. Many of these same chemicals are being used in the process lamination of the socket. Thus, possible hazardous gasses could be formed and accumulate in the body of patients who are being exposed to these prosthetic sockets. Table 1 describes the petrochemical substances with their in-

Table 1. The petrochemical substances with their ingredients used in a prosthetic socket

\begin{tabular}{ll}
\hline \multicolumn{1}{c}{ Material } & \multicolumn{1}{c}{ Ingredients } \\
\hline Epox-acryl & 1. Styrene monomer \\
(epoxy vinyl ester resin) & 2. Vinyl ester resin \\
Epoxy acrylic resin & 1. Styrene monomer \\
& 2. Epoxy methacrylate resin \\
Epoxy resin hardener & 1. Benzine-1,3-dimethaneamine \\
& 2. Trimethylhexanedlamine \\
& 3. Parateriarybutylphenol \\
\hline
\end{tabular}

gredients used in a prosthetic socket [7]

These aromatic fat soluble compounds, which include benzene, acrylic resin, epoxy resin hardener, are of the most toxic form of petroleum concentrates. Each of these substances contains ingredients that can be associated to vitiligo, contact dermatitis [17], cancer, liver, and kidney damage, along with additional serious health complications $[10-13,16]$.

Therefore, the purpose of this research was to investigate if freshly made materials used in prosthetic sockets causes off-gassing that would penetrate the skin and cause damage to the kidneys or blood.

\section{Methods}

\section{Subjects}

Nine subjects ( 3 women and 6 men) were in the experiment. No restrictions were made in regards to each subject's height, and weight, and all were over 18 years of age. Also, the participants had good skin integrity and had no open wounds or sores during testing. The exclusion criteria involved those who were taking medication or any type of treatment that caused hemolysis of red blood cells. All methods and procedures were approved by the institutional review board of Loma Linda University. All subjects signed an informed consent. The general characteristics of the subjects are shown in Table 2.

\section{Methods}

\section{Cuff lay-up}

A shape capture was made for each subject so that an appropriate fitting cuff was laminated for each individual in the study. The components of the lamination lay-up were one layer of perlon cloth, one carbon fiber cloth, and one nylon layer, which were infused with the epoxy acrylic laminating resin under vacuum for fabrication of the cuffs. The resin utilized contains styrene volatile organic compounds 485 $\mathrm{g} / \mathrm{L}$. The hardener used contains benzoyl peroxide in ester type plasticizer.

Table 2. General characteristics of subjects $(\mathrm{N}=9)$

\begin{tabular}{ccccc}
\hline & Age (y) & Height $(\mathrm{cm})$ & Weight $(\mathrm{kg})$ & BMI $\left(\mathrm{kg} / \mathrm{m}^{2}\right)$ \\
\hline Mean (SD) & $25.1(2.8)$ & $167.6(12.3)$ & $68.8(13.7)$ & $24.5(6.4)$ \\
\hline
\end{tabular}

SD: standard deviation, BMI: body mass index. 


\section{$A-D$ strip (off- gas testing)}

The acid-detection strips used are manufactured by Image Permanence Institute, Rochester, New York. The A-D strip was originally used for monitoring the off-gassing of acetic acid in acetate film collections; however, it can also be used to detect other acids released by plastics, wood products, adhesives, paper and textiles. The strips are paper based indicators that utilize bromcresol green to detect the presence of acids. They will change from blue to green, and then to yellow if acid gasses are released. The color blue represents a $\mathrm{pH}$ of 5.4 and yellow represents a $\mathrm{pH}$ of 3.8. The strips come with a color key to assist in identifying results. No other special equipment is needed for testing with this device. The strips are simply to be placed next to the material being tested for off gassing. The A-D strips were placed inside the socket right after fabrication, and left inside between 48 hours.

\section{Urine testing}

Urine testing was performed with Multistix PRO urine test strips, manufactured by Bayer Corporation (Elkhart, Indiana). The Multistix PRO urine test strips consist of 10 different chemical pads that would react when immersed and then removed from a urine sample. The strips detect glucose, protein-high, protein-low, ketone, specific gravity, creatinine, $\mathrm{pH}$, blood, nitrite, and leukocytes.

\section{Glucose}

Glucose testing indicates the glycemic status of the individual and is used to monitor diabetes. The renal threshold corresponds to the plasma glucose concentration of 180 $\mathrm{mg} / \mathrm{dL}$, although there is wide individual variation [18].

\section{Ketones}

Ketones are products of body fat metabolism and are not normally found in urine. Ketonuria is mostly associated with uncontrolled diabetes, but also can occur with carbohydrate-free diets, starvation and pregnancy [1]. Urine ketone testing is important to monitor in type 1 diabetes. Ketones present in the urine may indicate ketoacidosis, which requires immediate medical attention [19].

\section{Specific gravity}

Urinary specific gravity (USG) relates with urine osmolality. This test reveals the hydration status of the individual. Normal USG ranges from 1.003 to 1.030 . Readings under 1.010 indicates relative hydration and read- ings greater than 1.020 indicates relative dehydration [19].

\section{Blood}

The test for blood detects peroxidase activity of red blood cells. However myoglobin and hemoglobin will also catalyze this reaction, so a positive test result may indicate hematuria (urinary tract infection [UTI], trauma, cancer, or other serious conditions), myoglobinuria, (muscle damage), or hemoglobinuria (breaking apart of red blood cells) [20-23].

\section{$p H$}

Urinary $\mathrm{pH}$ ranges from 4.5 to 8 , but should be slightly acidic, 5.5 to 6.5. Urinary $\mathrm{pH}$ reflects the serum $\mathrm{pH}$ [20-23].

\section{Nitrite}

Nitrites are not normally found in urine, but results when bacteria reduce urinary nitrates to nitrites. A positive result indicates that these gram-negative and gram-positive organisms are present in significant numbers. A positive result may indicate UTI [20-23].

\section{Leukocytes}

Leukocyte esterase is produced by neutrophils and may signal pyuria associated with UTI [24-26].

\section{Protein}

Urinary proteins excretion is an important index for clinical evaluation of renal diseases. Proteinuria is an important symptom in renal disease [2]. Urine test strips are used to detect chronic kidney disease (CKD) and is also a possible indicator of cardiovascular disease. Diabetic kidney disease and the severity of glomerular, proximal tubular, and distal tubular damage are high in patients with albuminuria, as expressed in elevated protein reading in urinalysis [24-26].

\section{Creatinine}

Creatinine is a waste product produced by muscle action and when the individual digests meat [5]. Healthy kidneys remove creatinine from the blood which is then excreted through the urine. Normal ranges for urine creatinine are (male 0.8 to $1.8 \mathrm{~g} /$ day, female 0.6 to $1.6 \mathrm{~g} /$ day).

High creatinine readings indicate kidney damage [24-26].

\section{Protein creatinine ratio}

The protein to creatinine ratio is a reliable screening tool for CKD. This test is used to rule out significant proteinuria. Abnormal readings on a consistent basis should be followed 
up with further testing. As urinary protein loss increases, the percentage of albumin to total protein increases. The ranges of normal readings are as follows [27,28]:

Negative $\mathrm{mg} / \mathrm{dL}$ protein: $50-400 \mathrm{mg} / \mathrm{dL}$ creatinine

$15 \mathrm{mg} / \mathrm{dL}$ protein: $0-200 \mathrm{mg} / \mathrm{dL}$ creatinine

$30 \mathrm{mg} / \mathrm{dL}$ protein: $0-300 \mathrm{mg} / \mathrm{dL}$ creatinine

100,300 , or $2,000 \mathrm{mg} / \mathrm{dL}$ protein: $0-400 \mathrm{mg} / \mathrm{dL}$ creatinine

\section{Procedure}

All subjects completed a consent form to participate in the research study. The participants agreed to wear a newly laminated thigh cuff which simulated an above the knee prosthetic socket in cross sectional area. After the cuffs were laminated, the A-D strips were placed inside to test for off-gassing. The strips were then removed and read before the cuffs were delivered to the subjects. Time, date and test results were recorded.

The subjects provided a urine sample in a clean and dry container prior to wearing the devices. The samples were analyzed using the Multistix PRO and analyzed by the Bayer Clinitek Status Urine Analyzer (GMI, Ramsey, MN, USA). The subjects returned to the lab to provide urine samples after wearing the devices for periods ranging at about 48 hours.

\section{Results}

After wearing the plastic cuff for 48 hours, the ratio of protein to creatinine in the urine was raised to an abnormal level in five out of nine subjects. Clinical proteinuria is usually indicated as a ratio of (300 mg protein) per (gram creatinine). Normal strip ratio results may occur in urines containing less than $80 \mathrm{mg}$ albumin/ $\mathrm{g}$ creatinine or less than 300 $\mathrm{mg}$ protein/ g creatinine (Table 3 ). One subject was accidently exposed to the laminate before the control period and showed an abnormal protein loss in the urine.

Four out of the nine subjects showed normal protein to creatinine ratios after wearing the device. Out of these four subjects, three had a body mass index over $30 \mathrm{~kg} / \mathrm{m}^{2}$ which suggests body mass may play a role as an insulator since these substances are fat soluble. Since these are fat soluble, they would be buffered in the blood by accumulation in body fat and significantly more exposure would be needed to raise the plasma concentration to a critical level.

The protein concentration that is normally present in urine is less than $15 \mathrm{mg} / \mathrm{dL}$ per day. Additionally, normal creatinine concentration in adults is 50 to $200 \mathrm{mg} / \mathrm{dL}$ per day. Therefore, any ratio greater than $30 \mathrm{mg} / \mathrm{dL}$ of protein to 200 $\mathrm{mg} / \mathrm{dL}$ of creatinine is considered to be abnormal and an indicator of kidney damage as shown in Table 3.

\section{Discussion}

We examined the safety of the materials used in prosthetic sockets, such as styrene monomer, vinyl ester resin, epoxy acrylic resin, benzene-1, and 3 dimethaneamine. Even though these materials allow for flexibility and comfort, by nature of the process of mixing the components of the resin together, they release gases as part of the process. The off-gases may be hazardous or damaging to human health [29]. Based on our findings, the use of chemicals (epoxy acrylic, styrene monomer and vinyl ester resin) in the lamination process produces fumes that penetrated into the body. This was evident by finding proteinuria post application of the laminated socket to the skin in thinner subjects. We conducted this study on ten healthy volunteer participants who agreed to wear a mock socket. The results imply kidney damage from these resins and bring subject safety into question. Research shows that exposure to lipophilic chemicals may even cause type II diabetes and heart disease

Table 3. Results of the urine analysis after more than 1 day after wearing the laminate

$(\mathrm{N}=9)$

\begin{tabular}{|c|c|c|c|c|c|c|c|c|c|c|}
\hline Subjects & Glucose & Ketone & Specific gravity & Blood & $\mathrm{pH}$ & Nitrite & Leukocyte & Protein & Creatinine & $\begin{array}{l}\text { Protein : } \\
\text { creatinine }\end{array}$ \\
\hline 1 & Negative & Negative & 1.02 & Negative & 7.5 & Negative & Negative & Negative & 100 & Normal \\
\hline 2 & Negative & Negative & 1.03 & Negative & 6.5 & Negative & Negative & Negative & 200 & Normal \\
\hline 3 & Negative & Negative & 1.02 & Negative & 7.5 & Negative & Negative & 30 & 200 & 150, abnormal \\
\hline 4 & Negative & Negative & 1.02 & Negative & 7.5 & Negative & Negative & 30 & 100 & 300 , abnormal \\
\hline 5 & Negative & Negative & 1.025 & Negative & 7 & Negative & Trace & 30 & 200 & 150 , abnormal \\
\hline 6 & Negative & Negative & 1.025 & Negative & 7 & Negative & Negative & Negative & 200 & Normal \\
\hline 7 & Negative & Negative & 1.03 & Small & 6 & Negative & Negative & 100 & 300 & 150 , abnormal \\
\hline 8 & Negative & Negative & 1.03 & Negative & 6.5 & Negative & Negative & Negative & 200 & Normal \\
\hline 9 & Negative & Negative & 1.02 & Negative & 8 & Negative & Negative & 30 & 50 & 300, abnormal \\
\hline
\end{tabular}


[30,31].

In the study, the laminated cuff was exposed to each patient's skin only for one or two days and an actual socket was not used. In reality, patients will have longer exposure to these laminated materials. In manufacture of prosthesis, depending on the level of amputation, more of the lamination materials can be used for making the socket. Not only surface area, but the thickness of the actual prosthetic socket can differ from our cuff. During definitive lamination more layers are used which can trap additional gases.

Research has been performed on other plastic materials that have been used in reconstructive surgery, and to replace large segments of blood vessels as well as many other applications. Chemical inertness and insolubility have given the impression that many plastics would be free of tissue reaction. Studies have shown this is not true. Also, carbon particles are capable of producing fibrosis when inhaled by humans or injected to the peritoneal cavity of animals [31,32].

Another study showed the adverse effects of organic polymers used in plasma extenders, tissue adhesives, bone cements, contraceptive devices, prostheses, artificial organs; food packing has produced cancer due to accumulative toxicity of the chemical used [33].

Future studies should be performed on actual patients who wear prosthetics. Also, the socket should be delivered immediately after fabrication and urine samples taken in 24-hour intervals for several days after delivery. Upcoming studies should include the permeability of the socket liners including gel and pelite. Also, further research should test the prosthetists of toxic levels of substances since they are exposed directly to the polymers.

It should also be important to conduct patient intakes which includes the assessment of renal function. Many patient amputees who require prosthetic devices may already have diabetic nephropathy. Some may be on dialysis. We do not how a sudden spike of renal toxic polymers may affect the renal system of such already renal compromised persons.

We should not only look into the off-gassing effects to patients, but we should also monitor the protein to creatinine ratio of practitioners. With the exception of sanding, the prosthetist completes fabrication of the devices without respirators, and usually within 24 hours of socket lamination when off-gasses are present.

Toxic aromatic chemicals induce serious health hazards. Styrene exposure is linked to ischemic heart disease [34-36]. There is a Hazards Identification for styrene (carcinogen) and vinyl ester resin in material safety data sheets. These substances are listed in the US Toxic Substance Control Act $[37,38]$.

There were some limitations to our study which include small study sample size, and limited urine samples. Also, non-amputees were not included in the present study so future investigation should include:

- Conducting of similar tests with a larger population and to test amputees, especially since the socket encompasses a larger surface area than the cuffs.

- Testing of the permeability of various socket liners to off-gasses.

- Investigating of the health status of long- time users of prosthetic devices, including adults with early age amputations, including trauma, proximal focal deficiency patients, or other congenital amputees.

- Investigating of the health status of practitioners- conduct urinalysis for protein to creatinine ratios over time.

- The urine test strips are most sensitive to albumin. Further urinalysis study could include detecting other proteins in samples which may indicate other body system disruptions.

- Conducting of more consistent well-timed urinalysis for a longer period to see when the protein to creatinine ratio returns to pre- device delivery levels in the further study.

\section{Conflict of Interest}

The authors declared no potential conflicts of interest with respect to the authorship and/or publication of this article.

\section{References}

1. Ziegler-Graham K, MacKenzie EJ, Ephraim PL, Travison TG, Brookmeyer R. Estimating the prevalence of limb loss in the United States: 2005 to 2050. Arch Phys Med Rehabil 2008; 89:422-9.

2. Adams PF, Hendershot GE, Marano MA; Centers for Disease Control and Prevention/National Center for Health Statistics. Current estimates from the National Health Interview Survey, 1996. Vital Health Stat 10 1999;(200):1-203.

3. Keogh K. Improving diabetes advice could reduce the need for amputations. Nurs Stand 2014;29:11.

4. Ahmad N, Thomas GN, Gill P, Chan C, Torella F. Lower limb amputation in England: prevalence, regional variation and relationship with revascularisation, deprivation and risk factors. A retrospective review of hospital data. J R Soc Med 2014;107:483-9.

5. Ahmad N, Thomas GN, Chan C, Gill P. Ethnic differences in lower limb revascularisation and amputation rates. Implications 
for the aetiopathology of atherosclerosis? Atherosclerosis 2014; 233:503-7.

6. Assi R, Al Azzi Y, Protack CD, Williams WT, Hall MR, Wong DJ, et al. Chronic kidney disease predicts long-term mortality after major lower extremity amputation. N Am J Med Sci 2014;6:321-7.

7. Smith DG, Michael JW, Bowker JH, American Academy of Orthopaedic Surgeons. Atlas of amputations and limb deficiencies: surgical, prosthetic, and rehabilitation principles. $3 \mathrm{rd}$ ed. Rosemont, IL: American Academy of Orthopaedic Surgeons; 2004.

8. Marks GE. Manual of artificial limbs ... an exhaustive exposition of prothesis. New York: A. A. Marks; 1905.

9. Watson BA. A treatise on amputations of the extremities and their complications. Philadelphia: P. Blakiston Son \& Co.; 1885.

10. Lesage J, Stanley J, Karoly WJ, Lichtenberg FW. Airborne methylene diphenyl diisocyanate (MDI) concentrations associated with the application of polyurethane spray foam in residential construction. J Occup Environ Hyg 2007;4:145-55.

11. Meylemans HA, Harvey BG, Reams JT, Guenthner AJ, Cambrea LR, Groshens TJ, et al. Synthesis, characterization, and cure chemistry of renewable bis(cyanate) esters derived from 2-methoxy-4-methylphenol. Biomacromolecules 2013;14:771-80.

12. Kääriä K, Hirvonen A, Norppa H, Piirilä P, Vainio H, Rosenberg C. Exposure to 2,4- and 2,6-toluene diisocyanate (TDI) during production of flexible foam: determination of airborne TDI and urinary 2,4- and 2,6-toluenediamine (TDA). Analyst 2001;126: 1025-31.

13. Kääriä K, Hirvonen A, Norppa H, Piirilä P, Vainio H, Rosenberg C. Exposure to 4,4'-methylenediphenyl diisocyanate (MDI) during moulding of rigid polyurethane foam: determination of airborne MDI and urinary 4,4'-methylenedianiline (MDA). Analyst 2001;126:476-9.

14. Vilanova WV, Carvalho-Junior JR, Alfredo E, Sousa-Neto MD, Silva-Sousa YT. Effect of intracanal irrigants on the bond strength of epoxy resin-based and methacrylate resin-based sealers to root canal walls. Int Endod J 2012;45:42-8.

15. Scarparo RK, Grecca FS, Fachin EV. Analysis of tissue reactions to methacrylate resin-based, epoxy resin-based, and zinc oxide-eugenol endodontic sealers. J Endod 2009;35:229-32.

16. Kolstad HA, Juel K, Olsen J, Lynge E. Exposure to styrene and chronic health effects: mortality and incidence of solid cancers in the Danish reinforced plastics industry. Occup Environ Med 1995;52:320-7.

17. Romaguera C, Grimalt F, Vilaplana J. Paratertiary butylphenol formaldehyde resin in prosthesis. Contact Dermatitis 1985;12:174.

18. Kark RM. A primer of urinalysis. 2nd ed. New York: Hoeber; 1963.

19. Graff L. A handbook of routine urinalysis. Philadelphia: Lippincott; 1983.

20. Harr RR. Medical laboratory science review. 4th ed. Philadelphia:
F.A. Davis; 2013.

21. Hook JB. Toxicology of the kidney. New York: Raven Press; 1981.

22. Spitalnik SL, Arinsburg SA, Jhang JS. Clinical pathology: board review. Philadelphia, PA: Elsevier Saunders; 2015.

23. Ricotta MC. A consumer's guide to laboratory tests. Amherst, NY: Prometheus Books; 2005.

24. Lippincott Williams \& Wilkins. Professional guide to diagnostic tests. Philadelphia: Lippincott Williams \& Wilkins; 2005.

25. Race GJ, White MG. Basic urinalysis. Hagerstown, Md: Medical Dept., Harper \& Row; 1979.

26. Rennke HG, Denker BM. Renal pathophysiology: the essentials. 3rd ed. Baltimore, MD: Lippincott Williams \& Wilkins; 2010.

27. American Society of Clinical Pathologists. Council on Clinical Chemistry. Workshop on urinalysis and renal function studies. Chicago: 1962.

28. Arneill JR. Clinical diagnosis and urinalysis. A manual for students and practitioners. Philadelphia and New York: Lea Brothers \& Co.; 1905.

29. Bourne LB, Milner FJ, Alberman KB. Health problems of epoxy resins and amine-curing agents. Br J Ind Med 1959;16:81-97.

30. Zeliger HI. Lipophilic chemical exposure as a cause of cardiovascular disease. Interdiscip Toxicol 2013;6:55-62.

31. Zeliger HI. Lipophilic chemical exposure as a cause of type 2 diabetes (T2D). Rev Environ Health 2013;28:9-20.

32. Mogensen CE, Schmitz O. The diabetic kidney: from hyperfiltration and microalbuminuria to end-stage renal failure. Med Clin North Am 1988;72:1465-92.

33. Montaguti P, Melloni E, Cavalletti E. Acute intravenous toxicity of dimethyl sulfoxide, polyethylene glycol 400, dimethylformamide, absolute ethanol, and benzyl alcohol in inbred mouse strains. Arzneimittelforschung 1994;44:566-70.

34. Matanoski GM, Tao XG. Styrene exposure and ischemic heart disease: a case-cohort study. Am J Epidemiol 2003;158:988-95.

35. Matanoski GM, Tao X. Case-cohort study of styrene exposure and ischemic heart disease.Res Rep Health Eff Inst 2002;(108):1-29; discussion 31-7.

36. Matanoski G, Elliott E, Tao X, Francis M, Correa-Villasenor A, Santos-Burgoa C. Lymphohematopoietic cancers and butadiene and styrene exposure in synthetic rubber manufacture. Ann N Y Acad Sci 1997;837:157-69.

37. Schwartz MD, Dell'Aglio DM, Nickle R, Hornsby-Myers J. Federal environmental and occupational toxicology regulations and reporting requirements: a practical approach to what the medical toxicologist needs to know, part 2. J Med Toxicol 2014;10:415-27.

38. Schwartz MD, Dell'Aglio DM, Nickle R, Hornsby-Myers J. Federal environmental and occupational toxicology regulations and reporting requirements: a practical approach to what the medical toxicologist needs to know, part 1. J Med Toxicol 2014;10:319-30. 